\title{
Aprendizado na Experimentação Animal. Aquisição de habilidades perceptivas, gestuais e afetivas
}

Iara Maria de Almeida Souza ${ }^{a}$

Resumo: Na biomedicina roedores são usados em larga escala na produção de conhecimento. A incorporação dessas criaturas à pesquisa, envolveu um radical processo de padronização genética delas, bem como dos protocolos e técnicas voltadas para seu manejo. A ênfase na padronização e normatização não deve, contudo, ofuscar o quanto de trabalho manual e artesanal é exigido nessa atividade. Para abordar tal aspecto da prática científica, este artigo explora o processo de aprendizado da manipulação de roedores, a partir de relatos feitos por pesquisadores que atuam em uma instituição pública de pesquisa biomédica, e mostra como a capacidade de agir com destreza neste contexto requer um refinamento das habilidades perceptivas, gestuais e afetivas, que levam em consideração a força e vitalidade dos animais.

Palavras-chave: Antropologia da ciência, Relação humano-animal, Experimentação animal, Habilidade, Aprendizado.

Os estudos sobre ciências (science studies) produziram uma transformação na concepção que temos do modo com se dá a prática científica. Antes deles seria fácil considerá-la sobretudo como atividade 'intelectual', racional, teórica e objetiva, distinta e até mesmo oposta a práticas leigas ou tradicionais caracterizadas como artesanais e assentadas em habilidades corporais. Tais estudos mostraram, entretanto, que as realizações científicas resultam de uma enorme quantidade de trabalho material, esforço físico e habilidades manuais, ainda que este

a Professora Associada, Departamento de Sociologia (UFBA).Email: imas@ufba.br. 
tipo de ação se faça acompanhar de complexos e sofisticados conceitos e dispositivos tecnológicos (Clarke \& Fujimura 1992; Leonelli 2009).

$\mathrm{Na}$ área de pesquisa biomédica, a experimentação animal é um exemplo de prática científica que exige de pesquisadores e técnicos dedicados a ela um trabalho artesanal delicado e minucioso (Leonelli 2009). À primeira vista tal afirmação parece contrastar com a crescente padronização observada na pesquisa experimental, envolvendo a uniformização genética dos animais (Rader 2004) e, de modo correspondente, das instalações, tecnologias e procedimentos de manipulação. Como podem se combinar padronização, uso intensivo protocolos bem definidos e tecnologias com a exigência de cuidado, atenção, destreza manual para a lida com os animais? Há efetivamente uma oposição entre esse tipo de habilidade e a exigência padronização/ uniformização/tecnologia?

A utilização de animais na pesquisa, a despeito de contestações trazidas pelos defensores de animais, é uma prática científica bastante estabilizada e padronizada. A existência de protocolos orientando o trabalho pode dar a impressão de que tudo que se passa entre humanos e animais é previsto, regulado e controlado, mas é preciso considerar que a necessidade de aprendizado dos protocolos e padrões de manejo dos bichos é sempre uma realização local e pessoal (Grasseni 2007), simultaneamente perceptiva e afetiva (Holmberg 2011). E a iniciação de cada novato no manejo dos bichos e suas sutilezas é um acontecimento pontuado por imprevisibilidades e inquietações efeito de sua potência vital e capacidade de mutualidade com os humanos.

A despeito disso, a antropologia da ciência dá relativamente pouca importância à especificidade da presença de animais em laboratórios e recintos de produção de conhecimento, ou melhor, ela se interessa mais pelos seus resultados (Birke 2003; Lynch 1988) do que pelo processo de trabalho em que estão envolvidos humanos e outras criaturas vivas. Talvez a pouca atenção dedicada ao tema resulte da ênfase concedida à agência de não humanos considerados em sua generalidade. $\mathrm{Ou}$ a própria circunstância nas quais se dá o enreda- 
mento dos organismos vivos nos dispositivos laboratoriais, reduzindo suas chances de resposta, tenha acentuado a instrumentalização de suas existências, de tal modo que eles são tratados como semelhantes a reagentes ou a outras substâncias e ferramentas de pesquisa (Rader 2004). À exceção de estudos sobre primatologia (Rees, 2007; Sá, 2013) e de alguns outros exemplos (Sá et al 2011; Carvalho 2015; Souza 2013), o tema da interação entre os pesquisadores e os animais têm recebido pouca atenção.

Em outros contextos de pesquisa, diferentemente, o interesse pelos animais tem se ampliado recentemente. Com efeito, desde seu início a antropologia foi pródiga em mostrar uma profusão de bichos, uma vez que suas pesquisas usualmente se voltavam para povos caçadores ou pastores, alguns animais chegaram mesmo a se tornar emblemáticos na disciplina como os galos em Bali e o gado bovino para os Nuer. Tais criaturas, entretanto, tendiam a figurar como seres passivos frente às ações e disposições humanas (Knight 2005), sendo considerados 'bons para comer' ou 'bons para pensar', ou seja, eram vistos em termos meramente instrumentais ou como símbolos culturais e o que importava efetivamente nos dois casos era a compreensão das formações sociais e das relações entre humanos (Mullin 1999). O renovado interesse pelos animais no presente se afasta dessas posições na medida em que eles são vistos como entidades ativas e participantes de pleno direito na vida social. A mudança no modo de abordar as criaturas vivas tanto produziu efeitos sobre conceitos tradicionais da disciplina, como o de domesticação (Swanson et al 2018) bem como abriu um novo campo de estudos designado como etnografias multiespécies (Kirksey \& Helmreich 2010) que aponta para os modos como a vida e a morte de vários organismos estão ligadas aos mundos sociais humanos. Quer seja na observação de práticas de caça, de pastoreio ou dos vínculos estabelecidos com animais de estimação, tais estudos acentuam o caráter ativo e responsivo dos animais e mostram que suas relações com humanos envolvem bem mais do que representações sociais ou existência de 
laços puramente instrumentais, além disso, acentuam o fato de ambos são coconstituídos por essas relações (Knight 2005; Holmberg 2011; Despret 2008).

Tendo isso em conta pretendo explorar neste artigo o modo como pesquisadores adquirem as habilidades requeridas para lidar com animais - não com equipamentos, textos, conceitos etc - em investigações experimentais, algo que exige o refinamento das capacidades perceptivas, corporais e afetivas no exercício de um ofício marcado pela exigência de padronização. $O$ material empírico que apresento aqui é resultado de uma investigação realizada em uma instituição pública de pesquisa na área biomédica. Os pesquisadores com os quais conversei, situados em distintos momentos da carreira, enfatizaram sempre que o aprendizado da lida com modelos experimentais é algo que se dá na prática. Embora todos tenham participado do curso teórico de manipulação de animais e considerem essa introdução ao trabalho experimental valiosa e necessária, pois nela são dadas instruções sobre os protocolos de cuidado e biossegurança, tal iniciação é, de acordo com eles, insuficiente para prepará-los para o trabalho experimental. Eles reconhecem a existência e a necessidade de normas e padrões para a ciência, mas valorizam a incorporação de um saber que implica em um refinamento da visão e do toque, que dá a eles destreza para a realização de seu trabalho.

Antes de prosseguir, entretanto, é importante lembrar, como argumenta Ingold (2000), que esta habilidade não pode ser pensada como mera propriedade do corpo humano individual, para compreender a sua natureza é preciso recolocá-la no contexto de um engajamento ativo de um praticante em seu ambiente, ou seja, em um campo relacional composto por entidades que não são meros objetos exteriores aos quais forças mecânicas são aplicadas, mas materiais manuseados com atenção, cuidado e sensibilidade na realização do trabalho. A destreza não está, portanto, na facilidade com que se realiza certos movimentos com precisão e rapidez, mas na capacidade de ser responsivo àquilo com que se lida, seja uma fibra para trançar um cesto ou 
animais de laboratório. No caso específico, trato de camundongos, ratos e hamsters com os quais pesquisadores têm que se haver na experimentação e do que eles ensinam, com seus corpos e ações, aos humanos com os quais convivem.

A referência a Ingold aqui não é casual. A maneira como os pesquisadores relatam seu aprendizado justamente parece se aproximar do modo como este autor aborda o processo de aquisição de uma habilidade. Segundo ele, o conhecimento/aprendizado não se faz a partir da transmissão de certos conteúdos mentais ou informações que são passadas adiante de geração em geração. Tampouco a habilidade é apenas uma aplicação de conhecimento adquirido. Ao contrário, o aprendizado envolve uma contínua recriação do conhecimento nos contextos de aprendizado e no engajamento prático do aprendiz com seu meio. As habilidades, por sua vez, são capacidades corporificadas de ação e percepção que as pessoas desenvolvem no curso das atividades práticas, através das quais um mundo se abre para elas.

Assim, na primeira seção deste artigo explorarei o modo como os pesquisadores distinguem aprendizado teórico e prático. Em seguida abordarei o processo de educação da atenção, ou seja, o modo como a capacidade perceptiva é treinada de modo a ampliar o discernimento do noviço com relação ao trabalho experimental. Como o aprendizado não depende exclusivamente de uma relação entre humanos, em que o mais experiente aponta para o iniciante aquilo que ele deve observar, os corpos e comportamentos dos animais também ensinam ao pesquisador o que merece ser levado em consideração e como proceder. Este é um dos tópicos desse artigo. Por fim, mostro que o processo de aquisição de habilidade envolve ainda um aprendizado acerca de como ajustar a intensidade dos afetos que emergem nas situações de encontro entre humanos e animais.

\section{Curso teórico e aprendizado prático}

Como disse, o trabalho com experimentação animal é uma prática científica altamente padronizada, assim como costumam ser os 
representantes locais das várias espécies que foram convocadas a participar dos experimentos científicos como modelos. As instalações nas quais vivem os camundongos, ratos e hamsters são resultado de um ordenamento que prevê o máximo de controle sobre o ambiente: há monitoramento do ar, da temperatura, da higiene, da água e alimentos, há disposições acerca dos fluxos de animais e pessoas, bem como há normas e protocolos de manipulação. Há equipamentos próprios para uso local como as caixas, ou microisoladores, estantes nas quais elas se encaixam permitindo troca de ar, lavadoras, aparelhos de autoclave, estufas, cabine de fluxos etc.

Qualquer um que ingresse nesse ambiente extremamente controlado, repleto de regras e entre em contato com modelos experimentais - seja pesquisador ou técnico - precisa passar pelo curso introdutório à manipulação de animais oferecido pelo biotério, voltado para o ensino das normas básicas de conduta na experimentação.

O termo 'teórico' usado neste contexto não se refere a um conjunto de pressupostos abstratos acerca do que é experimentação ou sobre fatores que têm relevância explicativa para a utilização de animais em pesquisa. Afirmar que o curso de manipulação de animais é teórico, significa, para eles, que nas aulas são exibidos vídeos, apresentados protocolos e dadas indicações sobre como proceder, sem que ninguém efetivamente toque em nenhum animal ${ }^{1}$, como diz Dário ${ }^{2}$, mestrando da instituição, eles não "põem a mão na massa". Dizendo de outro modo, o curso é teórico porque está distante do contexto de ação em que humanos e animais se encontram em presença uns dos outros. Por isso, embora a disciplina tenha importância, as informações transmitidas nela não preparam efetivamente para a atuação na manipulação de animais. Segundo os pesquisadores, para a aquisição das habilidades requeridas nesta tarefa é fundamental o aprendizado prático, apenas este os torna aptos para o trabalho experimental.

A noção de que o trabalho nessa área de ciência - não só na experimentação animal - é de natureza essencialmente prática, embora estejamos falando de produção de conhecimento científico, faz parte do 
modo como os pesquisadores compreendem seu ofício. Mesmo a discussão com literatura pertinente a um tema de investigação, atividade considerada como teórica, é de certo modo subordinada à dimensão prática da pesquisa, como diz Natália, doutoranda da instituição:

Ah, eu gosto mais da parte prática mesmo, experimental. Isso é o melhor que a gente faz. Mas antes de fazer o experimento a gente planeja muito, essa etapa é demorada, porque tem que fazer a revisão bibliográfica, para saber o que os outros laboratórios têm feito, né? [...] pra depois ir e fazer o experimento.

A revisão de bibliografia serve como um guia para a elaboração de novos experimentos, além de ser também, é claro, uma instância em que resultados de pesquisa mostrados nas publicações são confrontados com os achados do próprio pesquisador. Sem dúvida, pensando nesses termos, não é possível separar totalmente as duas instâncias, pois, como argumenta Rheimberger (1997), os dispositivos experimentais estão montados para resolver certo tipos de perguntas que são simultaneamente teóricas e práticas, contudo, é importante salientar que os pesquisadores nesse contexto, mesmo não desprezando a teoria, inegavelmente demonstram uma preferência por aquelas dimensões do seu ofício que envolvem trabalho manual e se iniciar nessa esfera da ciência implica em adquirir um certo repertório de habilidades, capacidades para agir e perceber em um contexto de engajamento ativo.

É justamente pelo aprendizado das técnicas experimentais que usualmente se dá a introdução de um estudante de graduação em um laboratório (embora não seja apenas esse tipo de atividade que lhe compete desempenhar, ele também apresenta, discute ou contribui para redigir textos, relatórios, faz cálculos estatísticos etc). $\mathrm{O}$ iniciante ingressa na instituição para atuar em um projeto específico, mas precisa dominar as técnicas mais usadas no laboratório ao qual está vinculado. A aquisição de um repertório amplo de técnicas, por sua vez, contribui para fazer dele um pesquisador bem formado e experiente, um participante de pleno direito em uma comunidade de prática. 
O aprendizado das técnicas começa sempre pela observação do trabalho feito por alguém mais experiente. Há uma espécie de mimese nesse primeiro momento, mas não se trata de uma imitação em que o iniciante meramente repete os movimentos do instrutor, ele tentar coordenar seus movimentos com o do outro ao mesmo tempo em que dirige sua atenção para aquilo que lhe é apontado (Ingold 2000). Assim, ele não só adquire destreza, mas o próprio mundo - ou melhor, um setor específico do mundo - passa a se revelar para ele como dotado de novas nuances (Latour 2004). É no acompanhamento de um colega traquejado que o novato aprende perceber os movimentos dos animais, características do seu corpo, modos de manejar os instrumentos e os bichos.

O processo de iniciação finda quando aquele que treina o noviço é capaz de reconhecer sua habilidade e conceder a ele um passe para que comece a realizar os procedimentos autonomamente. Esse passe é progressivo, na medida em que ele aprende e ganha confiança no modo de manuseio dos animais, o instrutor vai incumbindo-o de novas tarefas e ampliando o escopo do que pode executar sozinho. É comum que primeiro a pessoa aprenda a conter, depois a injetar, medir, entubar, fazer cirurgia, eutanasiar etc. Mas é bom prestar atenção, dizer que ele se torna capaz de fazer algo de modo independente, não significa desacompanhado, na maior parte das vezes tudo que envolve a lida com animais vivos é feito em dupla ou em grupos maiores a depender da tarefa a ser realizada.

Para entrar mais diretamente na questão será abordada, o aprendizado sobre manipulação de animais, vou deixar de lado a distinção entre os sentidos de prático e teórico neste contexto e fazer um pequeno relato do aprendizado de Dora, doutoranda da instituição, para depois retomar alguns aspectos importantes relativos à lida com os animais em pesquisa.

\section{A iniciação de Dora}

Vou narrar o primeiro encontro de Dora com animais experimentais, mas é preciso antes fazer uma advertência, sua experiência inicial 
foge parcialmente ao padrão de aprendizado no local, primeiro porque ela começou a trabalhar com experimentação animal um tanto tardiamente, no doutorado. Em segundo lugar, porque ela passou por uma situação mais atribulada do que a maioria experimenta. Ainda assim, essa história é importante porque a partir dela posso chamar a atenção para aspectos diversos do trabalho com animais na ciência e sobre os modos como se aprende a lidar com eles na prática.

Dora é jovem, pequena e magra, tem a pele branca, cabelos negros e lisos e fala de um modo confiante. No mestrado ela trabalhou em pesquisa com humanos, ou melhor com células e tecidos de rins humanos, para avaliar biomarcadores ${ }^{3}$ de doença renal. Pretendia no doutorado seguir nesta linha de pesquisa, mas a perda de uma fonte importante de financiamento do laboratório impediu que ela prosseguisse com o trabalho, por conta do alto custo dos reagentes. A saída para seguir com o doutorado foi se voltar para um campo de estudos tradicional na instituição dotado de mais recursos. Foi assim que ela passou a pesquisar leishmaniose fazendo experimentação animal. Como de costuma, quando um pesquisador se filia a uma linha de investigação, ele se engaja, enquanto novato, em pesquisas que já estão em andamento para aprender as técnicas e posteriormente, quando estiver apto, desenvolver seu próprio experimento.

Esta foi a primeira experiência de Dora com modelo animal. Não que ela tivesse passado sua graduação em biologia sem tocar em bichos, ao contrário, ela fez pesquisa com aranhas e escorpiões, trabalhando em um viveiro de animais peçonhentos. Mas ela diz, "lá [no viveiro] eu cuidava dos animais, não matava".

Antes de tocar em camundongos e hamsters, Dora passou pelo curso teórico sem embaraço e sem antecipar qualquer problema com a experimentação. Foi sem apreensão que ela chegou para início de seu treino prático, acontece que nesse dia um número expressivo de animais seria sacrificado, nessas ocasiões é comum que se organize uma espécie de mutirão para dar conta da missão. Dora foi arrolada nessa empreitada. Como era seu primeiro dia foi confiada a ela uma 
tarefa simples: aplicar uma injeção de anestésico no abdômen dos camundongos e assistir - para aprender - todo o complexo processo que se seguia à anestesia (do sacrifício à coleta de sangue, extração de órgãos e preparação do material para análise). Ela diz que seu estranhamento inicial foi tátil, ela se surpreendeu com a textura e a resistência da carne do camundongo à entrada da agulha. Depois ela se assustou com a reação dele à injeção, que era dada na barriga. Diz ela: "O susto dele, me dava um susto também...”

Quando o anestésico produzia seu efeito, o camundongo adormecia, era a vez do veterinário entrar em ação para avaliar clinicamente o animal, pesar, observar se havia alguma lesão ou outro sinal de problema, como perda de pelo ou ferimento. $\mathrm{O}$ veterinário olhava o bicho e Dora olhava tanto para ele quanto para o camundongo que era manipulado, ela redescobria no corpo do animal adormecido aquilo que seu colega apontava. Em seguida era o momento da coleta de órgãos para análise. $\mathrm{O}$ método de sacrifício usado era 'choque hipovolêmico', ou seja, o sangue do animal era retirado, causando sua morte. Como o camundongo estava anestesiado, isso não lhe causava dor ou mal estar. Ela diz:

Só que o corpo sente... reage de alguma forma. E o animal tinha espasmos muito fortes. Quando acaba mesmo o sangue, ele... Era como se fosse soluço, sabe? E aquilo me aterrorizou de um jeito que eu falava: 'Velho, ele tá sentindo! Ele tá sentindo! E eu já tava preparando outro anestésico e ele [o veterinário]: Não! Eles até perdiam um pouco a paciência comigo dizendo assim: "Isso aí é espasmo. Você tem que estudar a anatomia do animal pra entender que isso acontece". Eles são mais experientes do que eu, era meu primeiro contato. Aí ele tinha essa reação e aquilo foi aterrorizante pra mim, eu tive que sair pra tentar me recompor. [...] Mas é isso, até o quinto, sexto, depois... A triste verdade é que a gente se acostuma. Eu me convenci de que aquilo não era ele sentindo. Eu anestesiava e ficava aprendendo.

Ela aprendeu, adquiriu mais habilidades, iniciou seu próprio experimento, modificou o protocolo, em vez de choque hipovolêmico, para sacrificar ela recorre a overdose de anestésico. A coleta de sangue 
para análise, também necessária em sua pesquisa atual, é feita imediatamente após a morte do animal pela retirada, com uma seringa, do líquido diretamente do coração. Esta foi uma técnica que ela aprendeu e atualmente ensina a outros.

Dora atua agora na posição de quem introduz novatos nas técnicas de experimentação. Seu modelo experimental é o hamster, ela e seu auxiliar, Kaíque, acompanham um lote desses bichos por um período de três meses, com pontos ao longo do tempo para o sacrifício de alguns deles. A morte dos animais em sequências temporais determinadas permite aos pesquisadores acompanhar o desenvolvimento da infecção por leishmânia e os danos que ela produz nos órgãos internos. Os hamsters, segundo Kaíque, são mais tranquilos que os camundongos. Quando eles chegam para observá-los encontram-nos dormindo juntos uns dos outros, como se estivessem se aquecendo. Essa visão evoca uma sensação de ternura nos dois. Dora procura resistir a esse afeto, ao contrário de Kaíque que ao chegar e sair da sala de experimentação os cumprimenta com um tom de voz carinhoso; distingue alguns como mais 'bonitinhos' e ficou tentado a nomeá-los. Dora desencoraja essa espécie de subversão dos vínculos que eles deveriam ter com seus modelos experimentais. Para ela, a inclinação a tornar o bicho algo próximo do animal de estimação não é a atitude mais apropriada a adotar com hamsters que serão sacrificados em pouco tempo por eles mesmos.

Essa história revela, entre outras coisas, que para lidar com animais experimentais é preciso aprender a ver, tocar, realizar certas técnicas com precisão, ter discernimento do que acontece com o corpo do animal e também saber como manter a distância afetiva apropriada com relação a essas criaturas. São esses aspectos que explorarei nos próximos tópicos.

\section{Aprendendo a prestar atenção}

Cada novo membro do laboratório, como disse, passa um tempo acompanhando alguém mais versado na experimentação animal para 
aprender na prática o que fazer com os bichos. No passado havia um técnico, Prof. Luciano, cuja missão era ensinar a todos os novatos os procedimentos, os cuidados e o respeito aos animais. Diz Joana, doutoranda da instituição:

Aí a gente tinha o [técnico], a gente chamava de Professor Luciano, ele era biólogo e treinava os alunos, né? Então aprendi muita coisa com ele, a pegar, a não estressar, a ter cuidado, respeito ao animal, né? Isso foi legal, isso de ter a pessoa experiente do lado.

Depois de sua morte, nenhum outro técnico o substituiu. Em parte isso reflete as transformações na organização de trabalho experimental. Antes a divisão entre o laboratório e o biotério, bem como a separação entre experimentação e cuidado eram mais fluidas. Alguns laboratórios mantinham animais em suas dependências de tal modo que os pesquisadores tinham uma convivência cotidiana com eles. Atualmente os bichos vivem apenas no biotério, pesquisadores se deslocam até lá quando têm alguma manipulação a fazer e deixam o local assim que finalizam a tarefa. Os animais ficam aos cuidados de técnicos, que no passado, além de zelarem por eles, auxiliavam os pesquisadores na experimentação. Tal cruzamento entre cuidado e experimentação já não acontece. Por muitos motivos, inclusive pela necessidade de centralizar todas as tarefas que dizem respeito à manipulação do animal vivo no biotério (Teixeira 2012). Também não há mais uma única pessoa encarregada do ensino, como o professor Luciano. Agora são colegas de laboratório, por vezes apenas um pouco mais avançados na arte da experimentação, que instruem os novatos.

$\mathrm{O}$ aprendizado com pessoas próximas em termos de hierarquia na carreira não deve causar estranheza, se considerarmos que a manipulação de animais é usualmente uma atividade realizada por pesquisadores no início da vida acadêmica, eles são graduandos, mestrandos, doutorandos e pós-doutorandos. Profissionais em posição de maior senioridade participam eventualmente no trabalho direto de experimentação, eles costumam deixar essas tarefas para seus orientandos, enquanto cuidam de outros afazeres. Isso quer dizer que há sempre 
noviços se iniciando na prática experimental e que o novato depois de certo tempo se tornará professor. Em geral, o par formado por aprendiz e instrutor envolve um pós-graduando e um bolsista de iniciação, ambos sob a orientação de um mesmo supervisor.

O aprendiz acompanha seu instrutor na ida ao biotério, chegando lá ambos se paramentam com os equipamentos de proteção, jaleco, sapatilha, gorro, máscara e luvas e tem início o treinamento. $\mathrm{O}$ aprendizado mais básico é como segurar o animal. Quando chegam, para fazer qualquer coisa é preciso retirar os animais das caixas onde vivem junto com alguns companheiros e levá-las para a bancada ou para o aparelho do fluxo ${ }^{4}$. Ao retirar a grade que recobre a abertura superior do microisolador o pesquisador escolhe apenas um deles de cada vez, para evitar as tentativas de fuga. Um dos modos de pegar um camundongo é segurando-o pela cauda até pousá-lo sobre a grade, onde ele se sente firmar e seguro, então o pesquisador pode com mais tranquilidade apanhá-lo pelo dorso para fazer a manipulação: injetar alguma substância, administrar medicamento, medir a pata. Assim, seja qual for o tipo de experimento a ser levado a cabo, por mais complexo que seja, antes de qualquer coisa, é preciso saber fazer a contenção, sem apertar demais - para que o animal não sufoque - e sem deixá-lo frouxo para que ele não se volte e morda a mão de quem o segura, algo que inevitavelmente ele tentará fazer, principalmente nas primeiras manipulações, quando ele não está habituado a ser tocado. Se de um lado há um aprendiz humano, do outro, pode haver um animal também sendo introduzido no trabalho da experimentação.

O aprendizado da contenção, embora seja básico, não é necessariamente fácil, porque o animal não fica imóvel esperando que alguém venha pegá-lo. Tremer, executar os movimentos de modo desajeitado, ter um desempenho inseguro não é raro entre os novatos. Dário, estudante de mestrado, fala sobre sua dificuldade: "Eu passei um tempo só treinando a pegada, eu não tremia, mas deixava a cabecinha solta. Aí isso era um perigo porque podia morder, eu não ia me infectar, mas ia ser dolorido". 
Dário inicialmente acompanhava Elano, um mestrando. Este último pegava o bicho, mostrava como fazer a preensão, soltava e era vez de Dário segurá-lo e deixá-lo livre. Como dito acima esse aprendizado não foi célere para Dário, por isso ele se valeu de outros recursos para intensificar o treino. Ele passou a acompanhar Beatriz, sua colega, nas idas ao biotério e pediu permissão a Elano para treinar com alguns animais do grupo controle - não contaminados - que seriam sacrificados ao fim de um experimento. Com esses camundongos ele treinou seguidamente a pegada até conseguir aprimorar a preensão. Ele diz: "eu expunha muito os meus dedos, quando ele vinha, já achava meu dedo, aí mordia, na verdade quando você vai pegando a prática, para de deixar seus dedos lá (rsrsrs), se deixar os dedos expostos, ele vem... abocanhar". O essencial para Dário, assim como para outros, foi a repetição dos gestos dirigidos aos animais.

Agora um membro apto do laboratório, Dário já não trabalha com infecção, ele testa uma droga para melanoma. Para fazer com que seus camundongos se tornem portadores do tumor ele introduz células cancerígenas na base de sua orelha, que é muito fina. A execução desse procedimento exige muita delicadeza e calma, o risco aqui não é o de contaminação, mas o de atravessar a pele sem perceber e, nesse caso, o tumor não se desenvolverá. Portanto, ao fazer isso, Dário precisa ficar muito atento ao que está manipulando, mas ele não o faz com o mesmo tipo de concentração tensa que, diz ele, era característica de sua iniciação.

A repetição também foi a chave para Beatriz aprender uma outra técnica, a entubação, frequentemente usada em experimentação para fazer um animal, possivelmente relutante, ingerir uma droga por via oral em quantidade precisa. A técnica envolve a administração de medicamento por meio da introdução de uma agulha de ponta esférica pela boca, através do esôfago até chegar à entrada do estômago, onde o remédio é dispensado. Beatriz aprendeu a entubar com seu instrutor, primeiro, como usual ele fez o procedimento dando indicações para ela. Depois ela começou a treinar nos animais do grupo controle, 
que não recebiam droga, mas água. Após muitas repetições ela adquiriu a destreza para fazer o procedimento

A gente segura, né? É, dorsalmente e deixa [o camundongo] ficar um pouco mais esticado, né?... Porque, mesmo a agulha tendo uma esferazinha pra você não perfurar o esôfago do animal, né, quanto mais retinho segurar melhor. Você passa a agulha e quando chega próximo do estômago, deixa a droga. Eu sempre tive cuidado, né? Eu ia devagarzinho, quando eu sentia uma barreirazinha, voltava. Sempre com calma, né? Pra não matar o animal, se perfurar é difícil ele não morrer.

Há duas coisas a acentuar aqui com relação ao papel da repetição. Como observa Ingold (2000), na aquisição de uma habilidade não basta observar o que é feito, é preciso reencenar, ensaiar o movimento para que o aprendiz ganhe destreza, mas o que se ganha com a repetição, entretanto, não é a capacidade de realizar a ação em uma sequência fixada de instruções, mas uma ampliação da sensibilidade para com o aquilo a que o gesto se dirige. Também, ainda argumenta Ingold (2000), a reiteração permite uma gradual sintonização de movimento e percepção de modo que a pessoa se torne mais sensível àquilo que manipula de tal modo que seus movimentos se tornam continuamente responsivos à modulação do material, como faz Beatriz ao entubar o camundongo, ele recua e volta porque sente a resistência do corpo do animal. Por fim, o trabalho aprendido exige concentração, mas quando o praticante se torna destro na execução de uma tarefa, esta não suscita tanta tensão e fixação da atenção, características da atuação do iniciante. Dário diz que mesmo sendo cuidadoso, sua atuação se tornou mais relaxado, ainda que demande monitoramento contínuo. De modo semelhante o trabalho de Beatriz envolve hesitação, correção, cuidado para que a operação seja bem realizada (Patchett 2016).

Um estilo descuidado, dizem alguns pesquisadores, pode levar a falhas mesmo naquelas tarefas básicas de contenção realizadas por pessoas experientes. Diana, por exemplo, afirma que quase todos os pesquisadores já foram mordidos em algum momento: 
Porque assim, você fica tão confiante que... você baixa a guarda, né? Porque têm algumas linhagens que são muito dóceis, você mexe com eles de boa... Mas sempre vai ter um indivíduo daqueles que vai estar um pouco mais estressado. Então às vezes você baixa a guarda, "Ah, não vai fazer nada, não...”, entendeu? Mas ele pode morder.

Mariana diz que mesmo com experiência já levou algumas mordidas sem gravidade. Isso acontece, segundo ela porque:

Imobilizar o animal corretamente é difícil, é difícil. Eu percebo que tem alguns que têm uma personalidade muito forte, que dão mais trabalho pra segurar. Não sei, acho que eles respondem diferente... E depende da linhagem também, né? Porque camundongos podem ser tranquilos, mas tem o Black, eles são mais ariscos, né?

Saber manipular animais não impede as mordidas, contudo, ter experiência no manejo prepara o pesquisador para responder a elas. Janaína, uma pesquisadora experiente, foi mordida recentemente, ela diz:

Mesmo com prática as vezes não tem jeito, sabe, recentemente eu levei mordida de camundongo, depois de anos de experiência [...], eu estava com luva cirúrgica, quando ele me mordeu eu olhei, estiquei a luva pra ver se tava rasgada, não tava, aí senti aquela dor, mas continuei manipulando o animal [...] era uma dor insuportável, é uma coisa rápida, mas o dente é tão afiado... Na mordida, é preciso manter a calma, não pode largar o bicho de vez, é preciso segurá-lo pela cauda, para que ele largue o dedo.

Frente a uma mordida é importante não agir de modo impulsivo, tentando puxar o animal para longe do dedo, mas levá-lo de volta à grade para que ele sinta seguro e solte a mordida. Saber manipular o animal, portanto, não significa jamais ser mordido, mas ter o discernimento sobre como proceder caso isso aconteça.

Esses exemplos mostram que adquirir uma habilidade não implica em ter um desempenho automático, mas envolve, de um lado, aprendizado acerca de como calibrar a atenção, pois uma atuação relaxada, em que o praticante 'baixa a guarda' pode conduzir a erros na realização do trabalho. De outro lado, ser experiente torna a pessoa mais apta a lidar com as consequências de alguma ação inesperada. 
Esses relatos revelam ainda outro aspecto importante para a compreensão do aprendizado, não devemos nos deter apenas nas atitudes dos praticantes, aquilo a que sua atenção se dirige também produz efeitos, ensina como se deve proceder. No caso específico, estou falando dos animais, seus corpos e comportamentos.

\section{Animais também ensinam e aprendem}

No caso de Dora, cuja história foi narrada anteriormente, em seu primeiro contato com animais na experimentação, ela estranhou a resistência da carne do animal à entrada da agulha, se assustou com seu sobressalto, se apavorou com os espasmos resultantes do choque hipovolêmico. Todas essas surpresas que fizeram parte da sua primeira lição foram produzidas pelos camundongos em resposta ao que era feito com eles. Havia um instrutor guiando sua percepção, apontando para aquilo que devia ser feito ou visto, ainda assim era preciso que ela descobrisse no animal o que era mostrado.

Descobrir os animais, suas qualidades, seus comportamentos implica também em aprender a discernir as variações de indivíduos, linhagens e espécies. Dora diz:

Na verdade, cê só sabe [as diferenças entre as linhagens] depois... Tipo, eu sei agora a diferença de um A/J pra um Balbi pelo comportamento. Se botar um do lado do outro é nítido, o comportamento é diferente. $\mathrm{O} \mathrm{A} / \mathrm{J}$ é beeem tranquilo. Mal você precisa conter ele, ele deixa você fazer tudo, agora... O Balbi é bem menos calmo... Bota um Black aí do lado que você vai ver.... vai ser um sufoco pra fazer qualquer coisa.

Camundongos da linhagem black são sabidamente mais ariscos e inquietos que os suíços ou balbis. Entretanto, Beatriz habituada a lidar rotineiramente com os suíços, só se deu conta plenamente da distinção ao ser mordida por um black, mesmo sendo relativamente experiente. Há ainda uma outra característica distintiva dessa linhagem que permite a ela ser mais relutante à preensão, como diz Janaína, doutoranda da instituição: 
Porque a gente percebe comportamentos diferentes de linhagens. Por exemplo, o Black é muito bravo. E outra característica do black que demanda mais assim [atenção], ele é pior de conter porque tem muita pele. Então mesmo quando a gente pega aqui, a gente tem que... pegar uma quantidade muito grande de pele, senão ele vira. Mas tem que pegar com cuidado porque senão sufoca o animal.

Ou seja, essa linhagem apresentam qualidades que exigem destrezas diferentes dos pesquisadores que os manipulam.

Isso quer dizer que o próprio animal e seu comportamento colocam problemas para o manipulador resolver em sua prática. Então é preciso conhecê-lo. O veterinário, tutor de Dora em sua primeira experiência, recomendou que ela estudasse anatomia para saber o que acontecia no choque hipovolêmico. Mas não é por intermédio da literatura que os pesquisadores iniciantes conhecem as peculiaridades dos bichos, é quando se defrontam diretamente com eles e os observam. É pela memória da mordida, pelas dificuldades em conter um camundongo black que Beatriz, Janaína e outros aprenderam a diferenciá-lo.

Há também diferenças entre as espécies. Kaíque trabalha com hamsters e teve que aprender com eles o modo correto de tocá-los:

E hamster as vezes você vai pegar e toca no local que ele não quer, ele vira pra lhe morder, você tira a mão correndo (rsrs). [...] Tipo assim, agora já sei que em tal parte eu não posso pegar. A experiência com eles ajuda muito a saber o que fazer. Eu sei que se eu tocar na barriga dele, ele não vai gostar e vai querer me morder. Eu sei que se eu tocar na parte de cima da cabeça ele fica mais quietinho.

Há ainda outros aprendizados sobre os corpos que precisam ser incorporados em muitas técnicas corriqueiras na experimentação, como localizar o coração do camundongo sem abrir o corpo para retirar sangue desse órgão, ou conhecer a sobreposição de camadas que recobrem o abdômen do camundongo para recuperar células do sistema imune do bicho. Também se aprende sobre o melhor meio de dar uma injeção na cauda de rato, algo que demanda esforço porque, por um lado, o bicho não fica parado à espera da entrada da agulha, de outro, porque o vaso sanguíneo não é imediatamente visível. Nara diz: 
Porque eu ia injetar, o rato fica assim sacudindo a cauda pra todos os lados, eu dizia: Aí eu não vou conseguir injetar nunca! Se ele não relaxasse, eu não ia conseguir fazer isso. Pegava, Seu Benedito segurava a cauda, pronto. Passava uma água morna com gaze pra aumentar a dilatação, aí o vaso dilatava um pouco pra eu poder enxergar, senão eu ia ficar furando, furando... [...] Então da primeira vez, claro, o animal ficava super agitado... Depois, com o passar do tempo, isso já não era mais um problema.[...] Na primeira reação, quando você pega, o animal tá estressado... Da segunda mais ou menos... Depois que você passa um mês fazendo tratamento, você tira o animal, bota ali... Ele não tem mais aquela resistência...

$\mathrm{Na}$ história contada por Nara, ela precisou encontrar o modo de injetar o medicamento na cauda do rato, recorrendo a um artifício para encontrar o vaso e contando com o auxílio do técnico, Seu Benedito, para contê-lo, mas ao longo do experimento, por conta da regularidade das manobras feitas, os bichos tiveram tempo de se acostumar à situação. Joana, que também tirava sangue da cauda de camundongo, diz:

A parasitemia é um pouquinho chata mesmo, eles não gostam muito não (rsrsrs) que você faz um furo e tira o sangue do rabo, eles ficam meio agitados... [...] Depois de um tempo, quando você pega, eles já não fazem aquela arruaça toda, né? Talvez porque sabem que vão ser retirados e colocados na caixa novamente...

Esse parece ser o padrão quando se trata de manipulações constantes, ao longo do tempo os bichos se tornam menos relutantes a serem tocados, a receberem medicação, injeção. Quando isso não acontece, é um sinal que precisa ser interpretado como relevante e não um fato fortuito, foi o que aconteceu no experimento de Janaína, depois de algumas aplicações de um medicamento, ao invés de se habituarem ao procedimento, eles se tornaram cada vez mais resistentes e estressados, tentavam fugir e faziam 'barulhinhos', ela então decidiu interromper o teste porque provavelmente aquela droga estava produzindo algum efeito colateral intenso e doloroso, embora ela não tivesse certeza disso.

A agitação, a sonorização, as tentativas de morder são indicações dadas pelos animais de sua potência e vitalidade, mas os bi- 
chos também dão sinais de vida mesmo quando não estão em movimento de contraposição ao pesquisador que tenta manipulá-lo. Por exemplo, quando um camundongo ou rato recebe uma dose de anestésico, antes de fazer qualquer coisa com animal é preciso que o pesquisador se certifique de que o bicho efetivamente já não é capaz de sentir dor. Isto acontece porque, mesmo havendo um cálculo para dosagem da droga, nem sempre os resultados são homogêneos. Há um teste simples, tocar com a pinça o pé do bicho e verificar se ele esboça algum tipo de reação, caso contrário, é possível prosseguir com o procedimento. Nem sempre isso basta. Nara vai em busca de outros sinais antes de se dar por convencida de que a anestesia foi efetiva:

A orientação é: você anestesia, aguarda um pouco, pega uma pinça, toca em pontos estratégicos, no solado da pata você faz um aperto, se o animal não reage de forma alguma [ele está anestesiado]... e também você sente quando a pata tá relaxada e quando ela tá tensa. Enquanto ela tá tensa, o animal não está anestesiado. Tem também a coloração da íris, entendeu? Quando o animal tá relaxado, ela muda. [...] você começa a perceber que a dilatação aumenta, então você vê que o animal tá anestesiado, tem também a respiração... Monte de coisa que a gente vai aprendendo com o passar do tempo.

Aprender a lidar com animal não é apenas incorporar certos protocolos, como o que determina a quantidade de droga a ser administrada para que a anestesia se produza, implica também em estar preparado para as variações nas respostas dos bichos, para a necessidade de observar se os anestésicos produziram efeito, se a agitação de camundongos às tentativas de pegá-los é simplesmente uma resistência esperada à manipulação ou se há nesse comportamento um sinal de que a droga utilizada está produzindo efeitos daninhos. Os protocolos não respondem a esse tipo de questão, só a atenção ao modo como os bichos reagem a essas e outras situações pode conferir algum tipo de orientação segura para agir, mas não além de qualquer dúvida. 


\section{Aprendendo a matar}

Usualmente a anestesia precede a morte do animal, é dada para que ele não sofra com a exansanguinação, o corte de seu abdômen para a retirada de material biológico e também pode ser usada para produzir uma overdose letal. Esses não são os únicos modos de tirar a vida de um bicho na experimentação, há outros com o uso da câmara de CO2 (não mais recomendado) ou o deslocamento cervical. Como na história de Dora, em geral de forma menos abrupta, todos os que se envolvem com experimentação aprendem a dar fim à vida dos animais, porque a morte após o fim do experimento é a sina de todos, mesmo os saudáveis (como os que pertencem ao grupo controle). Em certo sentido, os animais que atuam como modelos experimentais são criados para serem mortos, só então eles "fazem a transição entre uma materialidade vibrante do corpo vivo para uma forma diferente de materialidade silenciosa" (Schrader \& Johnston 2017:12) e cumprem seu destino, deixam a condição de animal natural - que vive, respira, morde - para se converterem animais analíticos, ou seja, em amostras, lâminas, material biológico (Lynch 1988).

A morte dos animais é um ônus também para os que trabalham com experimentação. A justificativa de que ela está serviço da vida de humanos e não humanos, não dissipa completamente o desconforto de se sentir responsável pelo fim da vida dos bichos, embora, como disse Dora, eles acabem se acostumando com isso. Todos os pesquisadores com os quais falei consideram que aprender a matar é a lição mais difícil, não do ponto de vista da destreza, por certo, mas por conta da inquietação afetiva e moral implicada no ato de tirar a vida, eles nem mesmo usam a palavra matar, mas eutanasiar - termo mais comum - ou sacrificar.

Mesmo sabendo antes de se iniciar na experimentação que sacrificar animais é uma parte do trabalho, o momento em que isto se efetiva não deixa de produzir - em sua concretização - um efeito imprevisto, quer seja pelas reações que o corpo do bicho pode expressar, como as contrações que aterrorizam Dora, seja porque a quantidade 
de vidas que são tiradas é maior do que imaginado ou porque aquele acontecimento continua reverberando em sonhos e pensamentos.

Há muitos relatos que falam da dificuldade de matar:

Porque a manipulação você fazendo da maneira correta você não machuca, não causa dano ao animal, mas na parte de sacrifício, eu tive que me preparar muito psicologicamente, né? Pra poder chegar e sacrificar o animal. Por mais que você anestesie, o animal vai sofrer, né? Então é difícil. (Beatriz, mestranda na instituição).

Então vi aquilo de uma forma terrível, eu pensei: "Meu deus... eu não vou me acostumar"... Eu acompanhava a técnica de laboratório da época [...]. Vinha todos os dias e ficava acompanhando. Eu não manipulava, até chegar o momento em que você tem que colocar a mão na massa mesmo... e era um terror. Então abri o animal pela primeira vez, "Meu deus, eu não vou conseguir. Meu deus do céu, não vou conseguir". (Nara, pesquisadora da instituição).

O que me incomodou assim na hora de fazer o sacrifício foi o fato da vida mesmo, de estar tirando uma vida, então isso inicialmente foi um choque, né? Porque nunca tinha matado animal na vida. Pra chegar e matar um animal que eu manipulei até determinado tempo, sabe, sacrificar isso é difícil mesmo. (Dário, mestrando da instituição).

Para lidar melhor com a situação de eutanásia, inclusive porque muitas vezes quando um experimento chega ao fim há muitos animais a serem sacrificados, muitos pesquisadores acabam por desenvolver modos próprios de realizar a tarefa. Joana costuma alisar os animais e pedir perdão a eles antes do sacrifício. Diana diz: "Eu faço de um em um ou de dois em dois. E a caixinha deles eu não deixo do lado pra eles não ficarem... Porque eles ficam agitados mesmo assim... Se você deixar a caixa perto, acho que eles sentem o cheiro ou alguma coisa”.

Não só o ato de tirar uma vida importa, faz diferença também o modo como isso é feito. Há quem não consiga realizar certo tipo de sacrifício. Janaína sabe que muitas pessoas recorrem ao deslocamento cervical porque é um modo rápido e indolor de eutanasiar um camundongo, mas ela não suporta fazer esse tipo de sacrifício, porque implica em usar as próprias mãos para matar. Ela prefere usar anestésico ou mesmo a câmara de CO2. Diana não tolerava ver animais serem 
asfixiados em um pote de vidro contendo éter em um laboratório no qual ela trabalhou anteriormente. A exsanguinação era quase intolerável para Dora.

Não é permitido aos pesquisadores, frente ao incômodo com a morte, simplesmente desviarem as vistas do acontecimento, eles não são eximidos de prestar muita atenção ao que estão fazendo, porque a preparação do material exige rapidez e destreza e deve ser realizada prontamente após a constatação de que animais já não respiram. Por exemplo, Dora precisa coletar sangue fresco, como ela prefere não recorrer ao choque hipovolêmico, precisa observar atentamente o animal para que no momento que logo após o último suspiro, ela recolha sangue do coração. Para fazer isso, ela precisou conter o sentimento de desconforto extremo que sentiu em sua iniciação. Foi assim, como todos os outros que permaneceram trabalhando com experimentação animal, os que não foram capazes de se acostumar a matar - isso não quer dizer se tornar indiferente - abandonaram esse tipo de pesquisa. Isso nos conduz ao último tópico deste artigo, que é o aprendizado dos afetos.

\section{Afetos na lida com animais experimentais}

Eneida era formada em farmácia e sabia quando decidiu entrar no laboratório que trabalharia com experimentação, portanto, não havia surpresa em ser designada para o aprendizado de manipulação de animais. Mas a previsibilidade do fato não impediu que ela sentisse um medo profundo nos primeiros encontros com camundongos. Ela levou um longo tempo até conseguir contê-los, depois foi difícil aprender a pegá-los na caixa. Eneida considerou esse aprendizado incrivelmente penoso, atualmente ela lida melhor com camundongos, que são pequenos, mas ainda não consegue pegar um hamster, que é maior. Ela teme a mordida deles, mas também tem um medo mais vago: "Não sei, acho que eles vão fazer alguma coisa comigo (rs)".

O medo é mesmo o afeto mais importante nos momentos iniciais do aprendizado, antes mesmo que alguns tenham a experiência 
de sacrificar animais e sentir o desconforto e a inquietação que isso produz. Seria fácil dizer, e talvez seja parcialmente verdadeiro, que o temor de Eneida é uma projeção dela sobre animais. Afirmar isso, entretanto, desconsidera que o objeto de sua apreensão é uma criatura viva que pode efetivamente reagir a ela. Mesmo sendo um medo pouco determinado, ele é vinculado à possibilidade do bicho responder, à sua força, movimento e uma potência vital que é responsiva e não plenamente controlável.

Joana, por sua vez, trouxe para a sua relação com os roedores do laboratório uma fobia de ratos que quase fez com que ela quase desistisse do trabalho. Ela diz:

E aí eu tinha muito medo, mais aí eu falei assim, eu preciso me [controlar], né? Todo mundo trabalha com animais, são de pequeno porte, aí fui trabalhando isso comigo, né? De conseguir manipular um animal e acabei conseguindo, realmente eu ainda tenho medo de ratos, mas não dos ratos daqui, eu não vejo eles como ratos. E hoje tenho até um carinho por conta justamente que o animal é experimental que nos serve [...].

Ela notava que de início, quando ela tinha mais medo, os animais também ficavam mais inquietos: "Eles pulavam (rsrsrs), eles pulam sabe, parece que percebem que você tá meio agitada, eles ficam... Não sei, eles ficam meio com medo, meio agitados". A existência dessa espécie de contágio afetivo é também algo enfatizado por técnicos trabalhando no biotério dessa instituição (Souza 2017). Para conseguir ter um controle sobre seu pavor e poder manejar os camundongos sem que eles se agitassem, foi importante para ela distinguir os roedores do biotério dos outros ratos, os bichos com os quais ela se relaciona são "limpos, fofinhos, pequenos" e são sacrificados pela ciência. O êxito na dissociação entre os animais de rua e os do biotério, bem como a familiaridade com estes últimos permitiram a Joana não só superar sua aversão, como desenvolver um carinho por eles e uma sensibilidade maior para tratá-los, principalmente depois de conviver com uma gata em casa, ela aprendeu com seu bicho de estimação o jeito 
de afagar seus animais experimentais. Ou seja, mesmo em um caso em que poderíamos dizer que há de modo mais claro uma projeção de sentimentos - uma fobia - sobre os bichos do laboratório, ainda assim as criaturas têm um poder de se deixar afetar - pelo medo de quem a manipula - quanto de contribuir para mudar os afetos, por um lado, ao exibirem sua diferença com relação aos temíveis - para Joana - ratos que vivem fora do ambiente do biotério, por outro, porque ela foi capaz de se deixar influenciar por sua gata e aprender novos toques e modos de olhar para os camundongos.

O medo de ser mordido não é um problema apenas para quem tem desde o início uma dificuldade com roedores, como Eneida e Joana, é um temor bem concreto para outros e está vinculado diretamente ao comportamento dos animais. Se os pesquisadores derem a chance, eles serão mordidos e a maioria deles já levou alguma 'mordiscada'. Em geral, quando o aprendizado avança e a pessoa adquire a destreza para conter corretamente o animal, a prática se torna mais segura e o medo tende a diminuir. $\mathrm{O}$ risco, então, é como disse Janaína, 'baixar a guarda'. Ter uma atitude relaxada demais, sem atenção à situação dá ao animal a chance de morder quem o manipula. É preciso, portanto, quando se ganha habilidade para lidar com os bichos, aprender a dosar o receio que se tem deles, pois o medo excessivo impede o bom manejo e a desatenção conduz a erros na manipulação. Talvez o termo melhor para nomear a boa atitude no manejo seja, nesse caso, confiança.

O medo não é único afeto que carece de regulação nesse ambiente, é preciso também ajustar o vínculo emocional que une o pesquisador ao animal. Assim como Joana acabou por desenvolver um carinho pelos camundongos, muitos outros pesquisadores, principalmente quando se trata da realização de experimentos mais longos em que os contatos entre eles e os bichos se dão mais amiúde, veem emergir uma afeição por seus animais experimentais, o que torna a realização da eutanásia mais perturbadora. Por isso é importante para Dora, por exemplo, refrear o sentimento de Kaíque, compartilhado em parte 
por ela, que o leva a falar de modo amoroso com os hamsters, a individualizá-los, a desejar nomeá-los como se fossem bichos de estimação. Não é raro que isso aconteça, apreciar os animais, acariciá-los, mas há uma linha que não se deve cruzar nessa simpatia pelos bichos, é preciso não confundir animais de trabalho com os de estimação e encontrar uma distância respeitosa com relação ao bicho, não sustentar uma proximidade afetiva que torna o sacrifício mais dolorido, nem rejeitar qualquer forma de afetação de tal modo que o manipulador se mantenha indiferente e incapaz de se abrir ao sofrimento que ele produz no animal. Adotar uma atitude respeitosa é encontrar a boa distância entre a indiferença e o amor (Goldman \& Barbosa 2018).

Os que se iniciaram há mais tempo como Nara e Joana lembram que professor Luciano ao introduzir os novatos no trabalho com animais, sempre enfatizava a necessidade de respeito. Não é exatamente claro o que isso significa neste contexto. A consideração pela vida e pelo sofrimento dos animais parece ser o ponto fundamental. Joana lembra que professor Luciano dizia que respeitar é cuidar. Mas também compõe o respeito a consideração de que a experimentação envolve o sacrifício de uma criatura viva, portanto, o trabalho tem que ser bem pensado, ele preciso conduzir a algum saber, o número de animais não pode ser excessivo, mas também não pode ser abaixo do recomendado para que o experimento não tenha que ser repetido com novos animais, é preciso diminuir o stress para que o bicho não padeça e para que os dados sejam bons. Uma história contada por Nara pode exemplificar como entender o respeito à dor e ao sofrimento. Quando ela começou a trabalhar com experimentação, os atuais anestésicos mais eficientes e potentes não eram usados. Para fazer a cirurgia nos bichos se usava éter. Se atualmente há variações entre os animais quanto aos efeitos das drogas anestésicas, no passado com o éter isso era muito mais comum porque não havia padronização da dosagem. Acontecia às vezes de um animal não ficar plenamente anestesiado. O que fazer? Era preciso esperar que o efeito passasse totalmente para tentar de novo ou adiar a realização do procedimento 
para outro dia. Não eram opções para Nara repetir imediatamente a carga de éter porque é quase certo que isso significaria provocar a morte do animal por overdose, nem realizar o procedimento sem a anestesia completa. Na primeira opção a vida do animal seria perdida em vão, na segunda ele sofreria uma dor que não era aceitável, em qualquer dos casos, agir assim seria uma desconsideração com a vida e o sofrimento da criatura.

\section{Conclusão}

O uso de organismos vivos não humanos é importante para produção de conhecimento na área biomédica. Roedores são usados em larga escala como modelos experimentais. Em seu processo de incorporação à pesquisa, eles passaram por um radical processo de padronização genética, além disso, suas vidas em biotérios e laboratórios são objeto de intenso controle e normatização técnica, o trabalho com eles é repleto de protocolos e altamente rotinizado. Se nos detivermos nos aspectos padronizados e normatizados desse tipo de atividade, esquecemos facilmente o processo de aquisição de habilidade e de formação dos novos membros de uma comunidade de prática, do qual a continuidade desse trabalho depende.

Neste artigo procurei justamente mostrar como se dá o aprendizado da manipulação de animais em pesquisa. $\mathrm{O}$ primeiro ponto a enfatizar é que mesmo se tratando de um aprendizado de ciência que depende de padronização do que é ensinado, a manipulação de animais é para os próprios pesquisadores um saber prático, envolvendo a aquisição de habilidades perceptivas, gestuais e afetivas. A incorporação desse saber se dá a partir de uma relação que o iniciante estabelece tanto com seu instrutor, aquele que mostra para ele os gestos a serem aprendidos, quanto com aquilo que deve ser observado, principalmente o corpo e o comportamento dos animais. A capacidade de agir com destreza está vinculada a um processo de educação da atenção, de um refinamento das habilidades em que o saber é descoberto no próprio fazer. Aquele que dá as indicações, guia para o significado que 
está no próprio mundo e nas coisas (Ingold 2010). É assim que se dá o aprendizado no laboratório e no biotério, os novos experimentadores precisam descobrir por si mesmo as texturas do corpo dos animais, seus movimentos, as variações individuais e de linhagens de comportamentos e corpos. Como argumenta Latour (2004), os aprendizes se tornam mais articulados e o mundo passa a ter mais qualidades reconhecíveis. Isso significa que padronização e rotinização de procedimentos e ações, não estão neste contexto em oposição à capacidade de ter discernimento, de reconhecer as variações e responder a elas. Além disso, adquirir destreza não implica em praticar certas tarefas de modo automático e sem hesitação, ao contrário, compreender o quanto de cuidado é necessário na realização de certos procedimento implica em estar pronto a fazer pequenos retornos e correções na sua execução. Os pesquisadores não trabalham com materiais inertes, mas com organismos que possuem força e vitalidade, capacidade de responder diferentemente, é preciso contar com essa potência do animais.

Por fim, o que foi mostrado nesse artigo também desafia certa oposição entre cognição e afeto. Aprender a manipular animais no contexto de pesquisa é também saber lidar com os vários afetos decorrentes do encontro de humanos com outras criaturas vivas, como o medo, a vinculação emocional, a inquietude frente a necessidade de matar. Para ser um praticante habilidoso, entretanto, o que se exige não é indiferença, nem apenas objetificação - o que talvez fosse esperado em um tipo de atividade que é, por um lado, instrumental, por outro, altamente padronizada - mas uma regulação das intensidades dos afetos e aquilo que eles chamam de respeito, uma abertura sensível para outras criaturas vivas, que reagem e sofrem.

\section{Notas:}

1 Programar o curso sem o uso de animais é uma diretriz ética para a redução do sofrimento e da morte de animais.

2 Todos os nomes que aparecem nesse texto são pseudônimos. 
3 Na medicina, um biomarcador é um indicador mensurável da presença ou da severidade de alguma doença.

4 O aparelho de 'fluxo' ou 'capela' é um equipamento criado para manter certas áreas estéreis para a manipulação de animais e de material biológico. Ele cria uma barreira de proteção ao interpor entre o interior e o exterior do aparelho um fluxo de ar que impede as trocas entre os dois ambientes.

\section{Referências:}

BIRKE, Lynda. 2003. "Who - or What - are the Rats (and Mice) in the Laboratory". Society and Animals, 11(3):207-224.

CLARKE, A. \& FUJIMURA, J. 1992. The Right tools for the job: at work in twentiethcentury life sciences. Princeton: Princeton University Press.

DESPRET, Vinciane. 2008. "The Becomings of Subjectivity in Animal Worlds". Subjectivity, 23:123-139.

GOLDMAN, M. \& BARBOSA, E. 2018. "A Maldição da Tolerância e a Arte do Respeito nos Saberes Afroindígenas". Trabalho apresentado no $42^{\circ}$ Encontro Anual da ANPOCS, Caxambu-MG.

GRASSENI, Cristina. 2007. Skilled Visions: Between Apprenticeship and Standards. New York: Berghahn Books.

HOLMBERG, Tora. 2011. "Mortal love: care practices in animal experimentation". Feminist Theory, 12(2):147-163.

INGOLD, Thimothy. 2010. "Da transmissão de representação à educação da atenção". Educação, 33(1):6-25.

2000. The perception of the environment: essays in livelihood, dwelling and skill. Nova York: Routledge.

KIRKSEY, S. \& Stefan HELMREICH. 2010. "The Emergency of multispecies Ethnography”. Cultural Anthropology, 25(4):545-576.

KNIGHT, John. 2005. Animals in Person: Cultural Perspectives on Human-animal intimacies. Oxford: Berg.

LATOUR, Bruno. 2004. "How to talk about the body? The normative dimension of science studies". Body E Society, 10(2-3):205-229.

LEONELLI, Sabina. 2009. "The Impure Nature of Biological Knowledge and the Practice of Understanding". In DE REGT, H.W., LEONELLI, S. \& EIGNER, K (eds): Philosophical Perspectives on Scientific Understanding, pp. 189. 209. Pittsburgh: Pittsburgh University Press.

LYNCH, Michael. 1988. "Sacrifice and the transformation of the animal into a scientific object: laboratory culture and ritual practices in the neuroscience". Social Studies of Science, 18:265-289.

MULLIN, Molly. 1999. "Mirrors and Windows: Sociocultural Studies of HumanAnimal Relationships". Annual Review of Anthropology, 28:201-224. 
PATCHETT, Merle. 2016. "The taxidermist's apprentice: stitching together the past and present of a craft practice". Cultural Geographies, 23(3):401-419.

RADER, Karen. 2004. Making Mice: Standardizing Animals for American Biomedical Research, 1900-1955. Princeton: Princeton University Press.

REES, Amanda. 2007. "Reflections on the Field: Primatology, Popular Science and the Politics of personhood". Social Studies of Science, 37(6):881-907.

RHEINBERGER, Hans J. 1997. Toward a history of epistemic things: Synthesizing proteins in the test tube. Stanford: Stanford University Press.

SCHRADER, A. \& JOHNSTON, E. 2017. "Considering Killability: Experiments in Unsettling Life and Death". Catalyst: Feminism, Theory, Technoscience, $3(2): 1-15$.

SOUZA, Iara M. 2017. "Afeto entre humanos e animais não humanos no biotério". Revista Brasileira de Ciências Sociais, 32(94):1-21.

SÁ, Guilherme. 2013. No Mesmo Galho: Antropologia de Coletivos Humanos e Animais. Rio de Janeiro: 7 Letras.

SWANSON, H., LIEN, M. \& WEEN, G. 2018. Domestication gone wild: politics and practices of multispecies relations. Durham: Duke University Press.

TEIXEIRA, Márcia. 2012. "Plataformas Tecnológicas e práticas de pesquisa em biomedicina - observações preliminares sobre o uso de dispositivos globais e instituições locais”. Sociologias, 14(29):312-336.

Abstract: In biomedicine rodents are used on a large scale in the production of knowledge. The incorporation of these creatures into research has involved a radical process of genetic standardization, as well as protocols and techniques for their management. The emphasis on standardization and normatization should not, however, overshadow the amount of manual labor and craftsmanship that is required in this activity. To address this aspect of scientific practice, this article explores the learning process of rodent handling, based on reports made by researchers working in a public biomedical research institution, and shows how the ability to act skillfully in this context requires a refinement of perceptual, gestural and affective skills, which take into account the strength and vitality of the animals.

Keywords: Anthropology of science, Human-animal relationship, Animal experimentation, Skill, Learning. 